\title{
Might Spinoza be Considered more as an Exponent of the Oriental Enlightenment, than as an Exponent of the Western Enlightenment?
}

\section{¿Puede considerarse a Spinoza como un exponente de la Ilustración Oriental más que como un exponente de la Ilustración Occidental?}

\author{
Miriam van Reijen ${ }^{1}$ \\ Universidad Nijmegen / Universidad Tilburg (Holanda)
}

Recibido: 02-02-18

Aprobado: 15-02-18

\begin{abstract}
In philosophy the relation between reason or wisdom and happiness is a returning theme, and so it is for Spinoza. In his Ethics he describes a path to happiness, but he states that reason often fails to reach it, because of the power of the passions. Only reason with an affective loading can be decisive. For this way of knowing Spinoza uses the word 'intuitive' knowledge. This has led to some interpretations of Spinoza's philosophy as mysticism. In my contribution I suggest that Spinoza who is sometimes considered as belonging to the Western Enlightenment, because of his emphasis on reason, can be considered also as a representative of the eastern enlightenment, because of the great value he attach to the intuitive knowledge.
\end{abstract}

Key-words: Wisdom, Happiness, Mysticism, Determinism, Buddhism, Intuitive Knowledge.

\footnotetext{
${ }^{1}$ (mt.vanreijen@avans.nl). Doctora en Filosofía por la Universidad de Tilburg y graduada en Filosofía y Sociología por la Universidad de Nijmegen. Sus últimas publicaciones son: Spinoza: de geest is gewillig, maar het vlees is sterk. Klement/Pelckmans, Kampen/Kapellen, 2008; Brieven over het kwaad: de correspondentie tussen Spinoza en Willem van Blijenbergh, Wereldbibliotheek, Amsterdam, 2012; Spinoza in bedrijf: van passie naar aktie.Klement/Pelckmans, Kampen/Kapellen, 2013 y Spinoza's bijdrage aan een actueel debat: bestaat de vrije wil? Vereniging Het Spinozahuis, Voorschoten, 2013.
} 


\section{Resumen}

En la filosofía la relación entre la razón o la sabiduría y la felicidad es un tema importante, y así es para Spinoza. En su Ética describe un camino hacia la felicidad, pero afirma que la razón sola no es apta para conseguir eso, a causa del poder de las pasiones. Solamente la 'razón afectiva' puede ser decisiva. Para esta forma de conocimiento Spinoza utiliza las palabras 'conocimiento intuitivo'. Esto ha llevado a algunas interpretaciones de la filosofía de Spinoza como misticismo. En mi artículo argumento que Spinoza, a quién se considera como perteneciente a la ilustración occidental, también se puede considerar como un representante de la ilustración del este, debido a la importancia que da al conocimiento intuitivo.

Palabras-clave: sabiduría, felicidad, misticismo, determinismo, budismo, conocimiento intuitivo.

\section{Regarding the possibility of being happy by philosophy}

Benedictus de Spinoza connects with a tradition of classical Western philosophy and with an authentic Jewish-Christian tradition. These traditions are concerned with a specific conception of wisdom and of happiness and with the relation between both. On the contrary is the idea that wisdom and happiness are necessarily linked to each other at odds with popular statements such as 'happiness is with the dumps', 'more happiness than wisdom', 'become wise through damage' and 'sadder but wiser'. So, if the relationship between wisdom and happiness is supposed to be close and even necessary, what kind of wisdom and what kind of happiness is meant? Although the philosopher is not worried about happiness, but about the truth, happiness can be nicely included, if happiness is inextricably linked to it. This is the case with, for instance, Epicurus, the Stoic philosophers, Augustine, Boëthius and Spinoza. And also in Eastern wisdom traditions, as Buddhism. What happens to you, is erratic, unpredictable, depending on external circumstances. Here the relationship between happiness and wisdom or philosophy seems hard to find. But feeling happy is an inner experience, a state of mind, and, more or less dependent of external circumstances. The two views of happiness, to be lucky or to feel happy, play a role through the whole history of philosophy. The 'more or less' is itself an idea or opinion and differs from total dependency to complete independency, like the Stoics assert. Spinoza agree with them that the passions arise from opinions and ideas, but he differs from them as for the possibility to change the opinions. But in any case, wisdom and happiness or joy have more to do with each other than is implied in the common language. There is a different way to be or become happy than through damage and disgrace. There 
is an opportunity to be happy through wisdom and insight. In any case, this point of view gives hope of making oneself more or less happy. Apparently, it is possible to feel happy in a bad or poor situation, while an objectively good situation does not give any guarantee of well-being. And when happiness is conceived as pleasure, as the satisfaction of as many quantitative needs and desires as possible, it will work counter-productive. 'Achieving happiness' presupposes something to pursue. The US Constitution states: the 'pursuit of happiness' is a right. From this idea follows a lot of unrest, striving, greed and snapshots of varying happiness and dissatisfaction. There are two risks involved with this conception of happiness as something that can be achieved in the future. Not achieving it or achieving it. If someone does not reach what he thinks to be happiness, he feels frustrated. If he gets it, he may become afraid of losing it. In addition, people often notice soon after getting what was supposed to bring happiness, that the possession of it is the end of entertainment. So, in any case, happiness does not appear to be in it. Spinoza describes this experience of an 'unlucky' path to happiness at the beginning of his Treatise on the Improvement of Understanding. The qualitative concept of happiness has to do with appreciating the here and now and not with striving and desiring. Following Buddhism all suffering comes from the desire and striving. In summary, the two concepts (extremely contrasted) of happiness differ on three points:

a) happiness is having something, or happiness has nothing to do with (having) something;

b) happiness depends on the circumstances, or happiness has nothing does not have to do with the circumstances;

c) happiness is only achieved by pursuing it or luck is not achieved by striving for it, it is already there.

It is this second conception of happiness that has a strong relationship with wisdom. The conception of happiness as inner peace or a quiet mind is the happiness that depends on a way of thinking, or wisdom. Happiness through wisdom consists of three interrelated aspects, which form the second side of the above three differences:

- happiness is understood as a state of mind, feeling (being);

- happiness is therefore independent of the circumstances;

- happiness is conceived as something that is already there, as peace of mind. 
This description shows a kind of a 'result', and the paradoxical situation is that this itself can be an ideal to be pursued. Spinoza gives his principles of reason, to reach a result that can be acquired through practicing. So demarcated, the question remains: how intimate or coincidental, separate or necessary is the relationship between this kind of happiness and wisdom? Wisdom means here: not to make mistakes, not to have inadequate ideas, superficial opinions, prejudices or dogmas. It has to do with knowing the true nature of reality, the real place of man in the universe. This knowledge starts as rational, scientific knowledge, but this kind of empirical knowledge is not the highest form of knowledge. Although it is true knowledge, it is limited, referring to the motivational force, because it lacks the force of imagination or feeling. In Ethics IV, P14 Spinoza states: "No affect can be restrained by the true knowledge of good and evil insofar as it is true, but only insofar as it is considered as an affect"' . It is the imagination with an affective loading that gives reason the motivational force to do or not to do what a person knows to be good or bad. Spinoza sees the relationship between wisdom and happiness as an inherently logical necessary relationship.

\begin{abstract}
After experience had taught me that all the things which regularly occur in ordinary life are empty and futile, and I saw that all the things which were the cause or object of my fear had nothing of good or bad in themselves, except insofar as my mind was moved by them, I resolves at last to try to find out whether there was anything which would be the true good, capable of communicating itself, and which alone would affect the mind, all others being rejected - whether there was something which, once found and acquired, would continuously give me the greatest joy, to eternity ${ }^{3}$.
\end{abstract}

This description shows a kind of end result, and the paradoxical situation is that this itself is an ideal to be pursued. It is, as Spinoza also indicates with his principles of reason, a result that can be gradually acquired through practicing. So demarcated, the question remains: how intimate or coincidental, separate or necessary is the relationship between this happiness and wisdom? What is wisdom? Wisdom means here: to have no inadequate ideas, no superficial opinions, prejudices or dogmas. Wisdom is insight into the true nature of reality, the place of man in it and seeing everything in the right proportions. This is the highest form of knowing for Spinoza. To have an intuitive perception of the individual nature and of one's own behavior, of all thoughts and all fortune as fully determined by God or the eternal nature. In this consists the highest happiness a human being can reach. For Spinoza the relationship between wisdom and happiness is an inherently logical necessary relationship.

\footnotetext{
${ }^{2}$ The Collected Works of Spinoza, Vol. I, Edwin Curley, Princeton University Press, Princeton, New Yersey, USA, 1985, p. 553.

${ }^{3}$ Ibídem, p. 7.
} 
For most things which present themselves in life, and which, to judge from their actions, men think to be the highest good, may be reduced to these three: wealth, honor and sensual pleasure. The mind is so distracted by these three that it cannot give the slightest thought to any other good ${ }^{4}$.

Spinoza therefore quickly comes to the conclusion that the old 'certain' is in fact insecure and it is even a certain evil, for instance, goods can easily be lost. What then is the true and highest good? According to Spinoza the 'true good' exists in 'the consciousness of the unity of Spirit and Nature'. And the 'highest good' is when someone does not pursue that 'true good' for himself alone, but tries to lead as many others as possible to the same insight, because men are social beings. The above mentioned 'true good' is the intuitive knowledge, that Spinoza describes in Ethics $\mathrm{V}$. This knowledge is a breakthrough, like in Zen Buddhism: somebody doesn't know (intuitively) something else but knows the same thing in a different way (than by reason).

In Ethics V Spinoza describes two different manifestations of the power of reason, and of the life under the direction of reason. He has mentioned both already at the end of Ethics IV, describing how both are related to the passions. He described the not yet 'free person', referring to the provisional remedy, the precepts which can help, while a life under the leadership of reason is not yet possible. The really 'free person' way of life is the effect of a deep understanding 'by heart' according to the rules of reason. In the beginning of part V Spinoza makes a step back. Maybe this is due to two causes. In the first place because Spinoza treated in part IV only the way how to live together with other people, in a nation. He described there how useful are the choices of the free man and how pleasant the coexistence of free people can be. The relationship with god and the associated deep happiness is not yet the theme, not even when it comes to the wise man. In the second place, in part IV the propositions are still formulated in a hypothetical way and Spinoza states at each statement express that 'the supposed of this proposition is false', because these propositions threat about people 'who are born free and remain so'. In a comment on another statement he stresses again the reserve he made already in the statement himself, 'I say as much as possible'. Thus in Part IV he outlined already an idea of the 'free man', as a man who does not exist and cannot exist in reality. It is just a model, an ideal to pursue. Maybe Spinoza writes this in order to arrive at the beginning of Part $\mathrm{V}$ where he introduces the precepts that are the first step in the right direction for those who in the meanwhile are motivated to start with it. In Ethics V Spinoza treats indeed regimen,

\footnotetext{
${ }^{4}$ The Collected Works of Spinoza, Vol I, Edwin Curley, Princeton University Press, Princeton, New Yersey, USA, 2016, p. 7/8.
}

Araucaria. Revista Iberoamericana de Filosofía, Política y Humanidades, año 20, n 39. Primer semestre de 2018. Pp. 297-310. ISSN 1575-6823 e-ISSN 2340-2199 doi: 10.12795/araucaria.2018.i39.14 
dictamenes, dogma. The use of the word 'should' here has a rare sense in Spinoza's philosophy, of a prescript, and not a necessity. Those prescriptions should be imprinted and applied. He refers for help not only to reason, but also to the imagination.

The best thing, then, that we can do, so long as we do not have perfect knowledge of our affects, is to conceive a correct principle of living, or sure maxims of life, to commit them to memory, and to apply them constantly to the particular frequently encountered in life. In this way our imagination will be extensively affected by them, and we shall always have them ready ${ }^{5}$.

The rules of life are not yet internalized. They are like the advice and exercises of the Stoic philosophers. The rules can help, but it is difficult, it is hard work. To again a statement from Wittgenstein, they are like the ladder that you can throw away when you arrive at the top. So, Spinoza distinguishes two ways to happiness. One way leads to a socially acceptable life on the base of religion, morality, laws and passions. This way can make a lot of people happy. The other way is the way of the sage who ideally lives following the internalized reason and so, without effort, is both social and happy. Spinoza's two-way model is fundamentally based on this distinction: the human being who lives in the imagination versus the human being who lives under the guidance of internalized reason, the intuitive knowledge. Spinoza makes a new dichotomy: life under the direction of reason or guided by intuitive knowledge. Ethics IV and V are often referred to in terms of the classic opposition passions versus ratio. In fact, Spinoza, however, makes a more fundamental distinction, namely between two different forms of knowing. He distinguishes inadequate knowledge and adequate knowledge, and calls the first in his Short Treatise the 'delusion' or imagination, and imagination in the Ethics. The passive versus the active affects are the respective effect of the two different ways of knowing. It is clear that a change in the affective domain can only take place through a change in thinking, as Spinoza himself indicates. When that change in thinking becomes more stable and profound, life is also more sustainable. Imaginary ideas such as superstition and normative ideas usually have an affective power. Not only because people prefer to believe what is more pleasant, but also because those views are internalized, once transferred by people in the immediate environment to whom they, when still children, were emotionally bound and from whom they were dependent. These views were and are often connected with the community, the group, the family, the tribe, the nation. They also have a complicated relationship with the self-image. After all, guilt is based on supposed power, namely that one had been able to do something else. It is a sad passion, and someone can suffer from it for

\footnotetext{
5 Ibídem, p. 601
} 
a lifetime. The effects of the two ways of knowing, imagination and reason, manifest themselves not only in passions on one side and happiness and peace of mind on the other. Spinoza also makes a distinction within the acquiescence. The acquiescence 'in se ipse' goes further than the 'acquiescentia vera animi': it is ego-less. The characteristic of Spinoza's two-way model on three levels of passions versus actions, faith and religion versus reason, acting on account of morality and laws versus on the basis of their own insight, is that the effect may be the same, but the way to it is different. The behavior can be the same, the motivation is different. The difference is always between being passive or active, being externally or internally motivated and between suffering and acting. There is also a difference between the state of mind while performing the same behavior, reluctantly or with pleasure, and also in the perception of being forced, obligated or feeling oneself and free. There is, moreover, a difference between unsteadiness, because a passion occurs always when the external cause is there again, while knowledge of what is good, remains constant. A clear example of this difference gives Spinoza himself, namely when he explains the difference between cooperation from fear for a common enemy versus cooperation from insight into the usefulness of cooperation. If somebody acts under the internalized direction of reason, the 'scientia intuitiva' life is easy. Not only the love for all that is, also happiness, joy and spiritual power, and also goodwill toward others are necessarily connected with this form of intuitive knowledge. The wise person knows that the other (wise) person is the highest good for man. He or she sees the added value of unity. He or she knows that democracy is the best form of government, that is, the most natural and the most human. The wise person is also a social person and not a lonely one. $\mathrm{He}$ or she wants to persevere, work and love and live together with others. He or she knows him or herself and his or her limitations. He or she is therefore also cautious with others and avoids raising hatred. For those who are internally motivated, there is no goal. 'The way is the goal', as is said in Taoism and in Zen Buddhism. That way is the happiness of the wise. The sage no longer needs the success, the fortune, to be able to keep going on, because he or she has the affectively loaded knowledge that his or her path is inherently good. The externally motivated people are guided by law, sanctions, religion, morality and passions such as fear or guilt, and suffer from it. The difference between a life under the guidance of reason and a life as a slave of the passions is the difference between suffering and leading. The happiness of the sage consists no longer in concrete actions and is not the reward for being virtuous, but the reward is the virtue itself: "Blessedness is not the reward of virtue, but virtue itself; nor do we enjoy it, because we restrain our lusts; on the contrary, because we enjoy it, we are able to restrain them".

${ }^{6}$ Ibídem, p. 617

Araucaria. Revista Iberoamericana de Filosofia, Política y Humanidades, año 20, n 39. Primer semestre de 2018 Pp. 297-310. ISSN 1575-6823 e-ISSN 2340-2199 doi: 10.12795/araucaria.2018.i39.14 


\section{Spinoza and Eastern ways of thinking}

There are two points of similarity between Western philosophy as philosophy, distinguished from something like a Western mentality, and the - generally speaking - Eastern ways of thinking. Both Western and Eastern thinkers traditionally see thinking (mind, consciousness) as more human and essential than passion or emotion. Both give more importance to inward actions than to the (superficial) outside world. We have seen this distinction already in the two views on happiness. Another point where they -again in general- differ from each other, is with regard to the ratio. Many Eastern thinkers see the ratio as a limited power related to happiness, salvation and true knowledge. This is evident in the double meaning of the word 'enlightenment': in Western history and philosophy the Enlightenment stands for (the age of) rational, scientific thinking. In Eastern philosophy 'enlightenment' refers to a 'higher' way of thinking, or even no longer thinking. For Zen Buddhism, instrumental reason can be only a condition: it can remove obstacles to liberation, happiness and the spiritual path. Rational thinking can be the necessary preliminary work, paving the way. For Spinoza reason is the second type of knowledge. Reason can correct the imagination, which is limited to sensory perception, and which -in a systematically ordered manner- is also the basis of a great deal of 'science'. Reason stands for the scientific knowledge of the 'general concepts', exposes the natural laws and reveals the (un)usefulness of something related to a goal. Reason is limited from two sides. On one side, because the body has always a limited perception and hence offers always distorted 'knowledge'. On the other side, the ratio is limited because intuition is a superior way of direct knowing. The limitation of the ratio double: in terms of knowledge, and in terms of motivation to act conform the rational knowledge. Another correspondence between Spinoza and certain Eastern forms of thinking is the idea that happiness and salvation are connected with wisdom. And there is the common insight that human being is not the center of the universe. Both, Spinoza and Eastern ways of thinking deny free will and a personal god. Especially because of his idea that reason is not the highest form of knowledge, Spinoza occupies a separate place within Western philosophy, and can be called an anomaly. As far as 'metaphysics' is concerned, it is a monist versus a dualistic view. There is one, infinite, eternal, substance. Man occupies no special or important place in nature, on the contrary. In short, both share a non-anthropocentric and non-anthropomorphism. Spinoza recognizes only natural causes. In both there is an important element of determinism. Important and essentially distinctive is the idea that everything is perfect. For Spinoza the world is not static, because everything that is, even if it is perfect at any moment, is always different. The world is dynamic, but everything is 
always actually perfect. To be perfect does not mean 'good' or nice. Perfect has no normative meaning. It simply means that everything always is what it is and could not have been different. Both Spinoza and many Eastern ways of thinking recognize different kinds of knowledge, the highest form being not the rational, but the intuitive one. Spinoza calls this the perspective of eternity. Buddhism sees this as a phase of enlightenment, to see oneself as dependent on the whole and in the whole. Only this is really understanding itself. The idea that our performances are imaginations and 'the map is not the landscape' also occurs in Eastern thinking. Not only thinking, but also knowing that we are thinking, being aware of our thinking, means that we also can realize that our ideas do not have to correspond with reality. In Buddhism, however, the illusory representations of ego, time and space are seen as inevitable both in simple everyday affairs, in our image of ourselves, of other people and of the world. We cannot have any other idea, but we can know that reality does not have to be the way we see and experience it. This knowledge makes us free; the reflection makes it easier to be unbiased and also to leave room for other ideas and opinions. All the passions are in Buddhism linked to the first kind of knowing: the imagination. As for Spinoza, the sage sees his happiness in the liberation of the passions. Spinoza's sage seeks the company of other sages, but knows how to adapt him of herself to other people and to given circumstances. Good and evil (morality, ethics) are (like all value judgments) concepts of the imagination. There is no right and wrong in nature. In Buddhism observing and perceiving is advised instead of judging. Depending on what is meant by 'perceiving' this could be a difference with Spinoza's view, when it is interpreted as denying that sensory perception is reflecting reality. This is itself already a judgment. Rather, it means taking the observation for what it is, without expressing its reality. And then we are back to Spinoza's view of the adequate way to understand the imagination as imagination.

The above is written mainly in Spinozistic terms. Therefore, now a representation of what the Buddha says about suffering, the four noble truths about suffering.

The first noble truth: life is suffering, that means, life is dependency, necessary undergoing, experience disorders through external effects on the body. Illness, death, impotence is unavoidable. It is the general human condition, it is not right or wrong, it is as it is. The second noble truth: the cause of (psychic) suffering is not accepting the unavoidable suffering of the first noble truth. It is not possible to free yourself from that suffering, but to accept this, makes you free from the (psychological) suffering. The third noble truth: abolishing the (psychological) suffering is possible, although difficult. The fourth noble truth: the road to liberation is the 8 -fold path. And there is a middle way that runs between extreme asceticism and frivolity. 


\section{Spinoza and mysticism}

In discussions about Spinoza, a distinction is sometimes made between two interpretations of Spinoza: as a rational Western philosopher or as a religious or oriental mystic. The rationalist interpretation puts him in the line of Descartes, with his scientific method and the logical way of reasoning and writing. The religious or mystical interpretation places him in the line of Confucius, Lao Tse, Buddha, Moses and the prophets and Paul. It emphasizes Spinoza's appreciation for intuition and interpret the intellectual love of god as a mystical experience, a mystical union with god. Samuel Melamed believes that Spinoza casts Eastern religious mysticism in Western terms, and states that Spinoza was the last great historical figure of spiritual thought in the $\mathrm{West}^{7}$. Hubbeling assumes that intuitive knowledge is possible, but based on the second form of knowledge. He equates intuitive knowledge with liberation, enlightenment, wisdom, happiness and peace of mind. Hubbeling points to a number of aspects (unity, perspective of eternity) in Spinoza's philosophy that also is found in mystical teachings ${ }^{8}$. But according to Hubbeling there are also differences: Spinoza has a different style of writing, he gives no moral recommendations, he does not describe the mystical experience, the experience of the unity with God, nor does he use these experiences in his argumentation. Jon Wetlesen, however, states that the necessary condition for intuitive knowledge following Spinoza is a mystical experience of unity 9 . So, Spinoza must have had this personal existential experience. Wetlesen attributes this personal mystical experience to Spinoza as a necessary condition for being able to write the Ethics. He also asserts that such a mystical experience of mystical unity is necessary to understand Spinoza's philosophy. He refers to an explicit presence of such an experience in the introduction of the Treatise on the Improvement of the Mind. Spinoza's idea that 'the essence of the special private body is to understand from the perspective of eternity and that only then other things can be understood and God can be seen as the cause' is only possible when it is based on a 'body-awareness experience'. That means, through an 'existential, participatory, intimate, personal experience of the knowing subject himself'. According to Wetlesen, the way of knowing that Spinoza describes in the Ethics is not sufficient for this. Only a personal experience can lead to the freedom and the happiness that Spinoza describes.

I have argued that Spinoza is not a 'pure' rationalist. He is perhaps a rationalist in terms of knowledge and method, but his statement that 'reason

\footnotetext{
${ }^{7}$ Samuel Melamed, Spinoza and Buddha. Visions of a death God. University of Chicago Press, Chicago, 1933.

${ }^{8}$ H.G. Hubbeling, Logic and experience in Spinoza's mysticism. In: Spinoza on knowing, being and freedom. In: J.G. Van der Bend (red.), Van Gorcum, Assen, 1974, p. 126-143.

9 J. Wetlesen, The sage and the way. Spinoza's ethics of freedom. Van Gorcum, Assen, 1979.
} 
cannot do anything against the passions, unless reason itself becomes passionate' is a central theme in his philosophy and is consistent with everything he writes. Also, his third and 'highest' form of knowing, which Spinoza himself calls intuitive, is an argument against the rationalistic interpretation. But that does not mean a 'mystical' dimension in his thinking. What is mysticism? What does a mystical dimension add to something? This is not clear and unambiguous. So, what is attributed to Spinoza, may be more than he intends. Wetlesen uses a circular reasoning: the criterion for mysticism is unity; Spinoza talks about unity, so it is mystical. In any case, Christian mysticism is quite different, because the personal relationship with God is essential. This is not only lacking in Spinoza, but even explicitly opposed. And if 'mysticism' does not mean anything else than being convinced of the insignificance of man in the universe with which one feels connected, what does the easy misunderstood word 'mystique' add to what Spinoza himself describes? The term 'religious' has the same meaning and is used by Spinoza himself. My interpretation is different. I suppose that Spinoza indeed is not a rationalist (in a narrow sense), because from both sides the ratio is put into perspective, limited, it has neither the last word nor the first. The ratio is embedded between the imagination (the organs of sense) and the intuition as the highest form of knowledge. Besides, our mind itself is limited because of the conatus, and the strict unity of body and mind.

\section{Joy through science}

In all of Spinoza's works, nature emerges in one way or another, not only as an object of study, but also in statements that support an interpretation of Spinoza as a naturalistic philosopher. In the Treatise on the Improvement of Understanding Spinoza describes the 'highest good' as the sense of unity with all that is, God or nature. This makes it possible to enjoy and enjoy unity with nature as well as unity with God. Einstein and Freud confirmed this.

Nature is always the same everywhere. Nothing happens that cannot be explained by the laws of nature. The knowledge of the second kind, reason, can give us knowledge of the natural laws. Even if the third kind of knowledge, the intuitive knowledge, is 'higher', that is not due to its content. The knowledge is exactly the same as the true and adequate knowledge of reason. Naturalism does not necessarily lead to a reductionist materialism. Only the way of knowing is of a different nature, more certain, unquestionably recognized. Naturalism means that someone states that nature is everything and natural laws determine all. Following Spinoza, nature is indeed all there is, the Substance or God. Nature has infinite attributes, but we humans only experience, hence know, 
two of them, body and mind. So, Spinoza's philosophy is not a materialism. His philosophy even allows the possibility of a kind of pantheistic absolute idealism, such as T.S. Sprigge defends ${ }^{10}$. Following Sprigge, Spinoza interprets the world as the symphony that God hears here and now. Sprigge refers to the idea of philosopher Ruth Millikan who sees God as Mother Nature's Mind ${ }^{11}$. When it comes to happiness (in the sense of peace of mind) it does not matter who or what determines, if there is anything that determines and it is not for man. A determinism, a pre-destination, by the God of Calvin or by the laws of nature, for happiness and happiness does not matter. It undermines, for those who have the great faith, which is rare in both cases, all fear and hope, guilt and pride, anger and sorrow, because one is safe in God's hand. It is decisive, to accept that there is something, not-human, that determines everything. Each form of determinism or pre-destination, be it the fate in the Greek tragedies, the God of Calvin or the laws of nature, for happiness it doesn't matter. Because it undermines, at least for those who have the great faith, which unfortunately is rare, all fear and hope, guilt and pride, anger and sorrow.

What is the relationship of a scientific, deterministic, naturalistic view, like that of Spinoza, with happiness and joy? Or, what advantages does this vision have, provided it is internalized in the way that Spinoza describes in Part V of the Ethics? Spinoza himself writes that the illusion of free will leads to more hatred of people than to the surrounding nature. Seeing people as a natural phenomenon, how strange that many may sound in the ears, prevents this. I have also shown that this has no effect on taking measures against harmful behavior, as we are used to doing with other harmful natural phenomena. The naturalism of Spinoza is evident in his theory of affect. The origin of affect is a natural given and can be fully explained by the nature of man and the nature of our surrounding nature. Spinoza deals with the influence of the ratio with regard to the passions, just like the influence of reason on other natural phenomena. The text from Ethics 3, preface is always quoted, in which he aligns the passions with circles, lines and planes. But in the Tractatus Politicus he expresses himself in a more plastic way: "[...] human disorders such as love, hatred, anger [...] not as faults of human nature [...] but considered as her qualities, which belong to her as well as that heat, cold, wrath and thunder and the like belong to the nature of the air". Reason can teach us to know and use the laws of natural phenomena, but not to change and control them, let alone turn them off. We can get to know the law of gravity, but not to disable it with reason. We can use that knowledge to build an airplane, for example. Not for nothing does Spinoza pay much attention to the human body. He states that we

\footnotetext{
${ }^{10}$ T. Sprigge, The God of Metaphysics. Clarendonpress, Oxford, 2006.

${ }^{11}$ Ruth Garrett Millikan, Language, Thought, and Other Biological Categories. Cambridge University Press, Cambridge, 2000
} 
can only know the working of the mind when we know the body. We still do not know the power and functioning of the human body at all, even now, 350 years after Spinoza. Spinoza's view of real freedom is also naturalistic and not idealistic. 'I call free that which exists and acts solely on account of the necessity of its nature [...] I do not allow freedom to exist in a free will, but in a free necessity.' Not only the 'sad passions', but also some positive affections are 'passive affections' for Spinoza, because they are based on inadequate representations and are undermined by a naturalistic vision. Examples of these passive affections are joy or love based on false expectation or lack of knowledge, self-glorification and pride. However, it appears that the loss of the good feeling caused by the loss of an illusion, can also have a positive effect. The loss of pride for example is richly compensated with a much more intense feeling of happiness, and gratefulness, just because something beautiful is happening, and not as a result of my exertion. I will briefly mention a few advantages of scientific naturalistic thinking. The assumption of purpose causes and of anthropomorphism in nature obstruct true knowledge. Only knowing the real causes leads to effective intervention and happiness. The idea that everything that happens was and is necessary and (in retrospect) could not have happened differently, contributes to clarity, security and peace of mind. This determinism should not be confused with fatalism and can in no way impede choosing and acting. To know that everything is explicable, because it has a natural cause, even without already knowing this cause, protects against being angry and feeling guilty. Knowing the cause(s) is a necessary condition to act successfully against diseases and other inconveniences. Spinoza supposes that his philosophy can promote peace, social unity, more understanding and seeing what unifies people instead of separates, leading thus to more tolerance. The true knowledge of the singular being is embedded in the knowledge of the laws of nature. But this knowledge has its effects only when it is not just the way of the rational knowledge, hence in the western idea of Enlightenment, of the laws of nature per se, but related to Spinoza's God//Nature//Universe. And therefore ' ... we rejoice, with the accompanying thought of God or Nature as the cause.' The radical determinism or naturalism does not deprive anyone of being virtuous, of the experience of freedom or of the mood of intense joy and happiness. On the contrary, because (in analogy with the reasoning in the subtitle of Spinoza's Theological-political Treatise) we can say: 'The necessity of everything in nature cannot alone be recognized while retaining individual freedom and true deep joy, but one cannot deny it without also abolishing freedom and especially bless!' 


\section{Bibliography:}

Curley, E., The Collected Works of Spinoza, Vol I, Princeton University Press, Princeton, New Yersey, USA, 2016.

Hubbeling, H. G., Logic and experience in Spinoza's mysticism. In: Spinoza on knowing, being and freedom. In: J.G. Van der Bend (red.), Van Gorcum, Assen, 1974, p. 126-143.

Melamed, Samual, Spinoza and Buddha. Visions of a death God. University of Chicago Press, Chicago, 1933.

Millikan, Ruth Garrett, Language, Thought, and Other Biological Categories. Cambridge University Press, Cambridge, 2000

Sprigge, T., The God of Metaphysics. Clarendon Press, Oxford, 2006.

Wetlesen, J., The sage and the way. Spinoza's ethics of freedom. Van Gorcum, Assen, 1979. 